\title{
COMBINED USE OF DIETARY PROBIOTIC AND ACIDIFIER FOR THE PRODUCTION OF ANTIBIOTIC FREE BROILER
}

\author{
Abdullah-Al-Masud, Md. Shawkat Ali and Muslah Uddin Ahammad*
}

Department of Poultry Science, Faculty of Animal Husbandry, Bangladesh

Agricultural University, Mymensingh-2202, Bangladesh

*Corresponding author: Muslah Uddin Ahammad; E-mail: muslah.ps@bau.edu.bd

\begin{tabular}{|c|c|}
\hline ARTICLE INFO & ABSTRACT \\
\hline $\begin{array}{l}\text { Accepted } \\
16.04 .2016 \\
\text { Online } \\
30 \text { April } 2016 \\
\text { Key words } \\
\text { Probiotic, } \\
\text { Acidifier, } \\
\text { Antibiotic growth, } \\
\text { promoter, } \\
\text { Broiler }\end{array}$ & $\begin{array}{l}\text { The effect of feeding probiotic (Bio-Top; Bacillus subtilis and Bacillus licheniformis), } \\
\text { acidifier (Sal-Stop), antibiotic growth promoter (AGP) or probiotic plus acidifier was } \\
\text { investigated in commercial broiler. A total of four hundred Cobb } 500 \text { day-old straight } \\
\text { run chicks were randomly distributed to } 5 \text { different dietary groups having } 4 \text { replications } \\
\text { each. The number of birds in each replication was } 20 \text {. The five dietary groups were as } \\
\text { control (basal diet; BD), BD containing AGP at a level of } 20 \mathrm{~g} / 100 \mathrm{~kg} \text {, BD containing } \\
\text { probiotic at a level of } 200 \mathrm{~g} / 100 \mathrm{~kg}, \mathrm{BD} \text { containing acidifier at a level of } 200 \mathrm{~g} / 100 \mathrm{~kg} \text {; and } \\
\text { BD containing an equal amount of probiotic plus acidifier ( } 200 \mathrm{~g} / 100 \mathrm{~kg} \text { ). Broilers that } \\
\text { received either probiotic, acidifier or a mixture of probiotic and acidifier ( } 1: 1 \text { ) exhibited } \\
\text { higher body weight gain, lower feed conversion ratio (FCR) and higher cost- } \\
\text { effectiveness compared with the broilers fed on control diet ( } P<0.05 \text { ). However, } \\
\text { feeding of diet containing both probiotic and acidifier resulted in the highest growth } \\
\text { rate and net profit in all dietary regimens. Broilers fed on probiotic and acidifier in a } \\
\text { mixture had FCR similar to other treatment groups. This study indicated that the diet } \\
\text { containing probiotic-acidifier mixture seems to be more cost-effective in promoting } \\
\text { growth performance of broilers, as an alternative to the AGP, as compared to the use } \\
\text { of probiotic or acidifier alone in the diet. }\end{array}$ \\
\hline
\end{tabular}

To cite this article: Masud AA, Ali M S and MU Ahammad, 2016. Combined use of dietary probiotic and acidifier for the production of antibiotic free broiler. Res. Agric. Livest. Fish. 3 (1): 127-137.

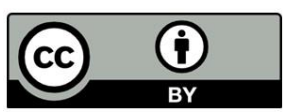

This is an open access article licensed under the terms of the Creative Commons Attribution 4.0 International License

www.agroaid-bd.org/ralf, E-mail: editor.ralf@gmail.com 


\section{INTRODUCTION}

Broiler production is one of the most important and promising sector in poultry industry in terms of advantage of quick return that plays a vital role in the economic growth of Bangladesh. It has been proven that the genetic potentiality of the fast growing commercial broilers is achieved in the shortest possible time by the application of modern nutri-biotechnology. However, the optimum growths of broilers are seriously hampered by the invasion of pathogenic microorganisms. In order to cope with the challanges of growth-inhibiting microorganisms, some antibiotics like bacitracin, virginiamycin, flavomycin, avilamycin, tiamulin, colistin sulphate, oxytetracycline, aureomycin, chlortetracycline, neomycin sulphate, erythromycin and enrofloxacin have been used for several decades in broiler feed at a sub-therapeutic level. Antibiotics are double edge weapon. Antibiotics that are used as AGP in broiler feed have been shown to increase meat yield and improve feed efficiency with substantial reduction in pathogenic bacteria in the host gut (Gaskins et al., 2002). They are also widely used in veterinary field for reducing the incidence of diseases. However, indiscriminate use of antibiotics in broiler production leads to the development of antibiotic resistant pathogenic bacteria, thereby causing resistance to medicines, persistence of infections and treatment failure. Several studies provided evidence that inappropriate and excessive use of antibiotics has led to the accumulation of their residues in edible broiler carcass which poses a major threat and potential risk to public health (Donoghue, 2003; ElKahky and Allam, 2005; Nisha, 2008; Shareef et al., 2009; Jallailudeen, 2015). In Bangladesh, a recent study has shown that high levels of residues of major antibiotics like tetracycline, ciprofloxacin, enrofloxacin and amoxicillin were found mostly in liver, kidney, thigh meat and breast meat of broilers (Sattar et al., 2014). The European Union has reported that about 25,000 patients died each year from infections caused by drugresistant bacteria, which is equivalent to $€ 1.5$ billion of medical healthcare costs (Ziggers, 2011). For this reason, most of the poultry meat consumer groups are avoiding meat from birds fed on diets containing antibiotics. In consequence, the European Union has banned the use of antibiotics in animal production since 2006 and other developed countries have limited the antibiotic use in poultry production. However, the ban of AGP demands the search for more suitable and safer alternatives to antibiotics that would promote growth, feed utilization and gut health without having any residual effect on poultry products. Recently, many feed additives referred to as natural growth promoters or non-antibiotic growth promoters have been evaluated which include probiotics, prebiotics, synbiotics, acidifiers, phytobiotics, etc. (Ricke, 2003; Hruby and Cowieson, 2006; Kocher, 2006; Alavi et al., 2012).

The term probiotic derived from Greek word "pro bios" which means "in favor of life" (Coppola and Turnes, 2004). According to the definition by $\mathrm{FAO} / \mathrm{WHO}$, probiotics are live microorganisms which when administered in adequate amounts confer a health benefit on the host (Fuller et al., 1989). Studies have shown that probiotics act as substitute for AGP (Tomasik and Tomasik, 2003), which have been used on poultry to increase weight gain (Kapil et al., 2015). Probiotics added to poultry feed help in the production of vitamin B complex and digestive enzymes, and stimulation of intestinal immunity, increasing protection against toxins produced by pathogenic microorganisms (Alexopoulos et al., 2004). In broiler, probiotic species such as Lactobacillus, Streptococcus, Bacillus, Bifidobacterium, Enterococcus, Aspergillus, Candida and Saccharomyces are widely used to prevent poultry pathogens and diseases and to improve growth performance of broilers (Zulkifli et al., 2000; Kalavathy et al., 2003; Kabir et al., 2004; Timmerman et. al, 2006; Awad et al., 2009; Lee et al., 2010; Kapil et al., 2015). However, combination of Bacillus subtilis and Bacillus licheniformis are widely used as health-boosting probiotic strains, which have been shown to aid in nutrient digestion and absorption and in creating the favourable conditions for beneficial bacteria (Kapil et al., 2015).

On the other hand, recent studies in poultry nutrition have shown that acidifiers (feed additives containing low-molecular-weight organic acids e.g. acetic, citric, lactic, formic, sorbic, ascorbic, propionic, fumeric and malic acid) act as antimicrobial and intestinal $\mathrm{pH}$ regulator which when used in poultry diets cause maximum utilization of feed and reduction in harmful bacterial population in the hosts' gut, improvement of performance and promotion of health status of poultry fed diets devoid of AGP (Skinner et al., 1991 and Kil et al., 2011). The organic acids (non-dissociated or non-ionised and more lipophilic form) can penetrate the bacteria cell wall and disrupt the normal physiology of certain types of bacteria (Kapil et al., 2015). It has been reported that acidifiers reduce Coliforms and Clostridia loads in the gut and increase the number of beneficial bacteria such as Lactobacilli in the ileum (Akyurek et al., 2011). 
Alhough there is an ample evidence for beneficial bacteria competing and excluding potential pathogens in the intestinal tract of chickens, there is evidence that probiotic strains fail to compete with harmful bacteria when the gut $\mathrm{pH}$ increases toward a more alkaline range due to inclusion of high protein and minerals in the diet or in a situation when harmful bacterial population is already high in the gut before probiotic administration (Edens et al., 1997; Edens, 2003; Kapil et al., 2015). Therefore, a favourable microenvironment (to stabilize the low $\mathrm{pH}$ ) is required which might be provided with the supplementation of acidifier in broiler diet containing probiotic to exhibit full potentiality of probiotic bacteria in the gut. However, limited evidence is available on the benefit of combining probiotics with acidifier in broiler diet in comparison to their benefit alone. In order for the elucidation of the effect of probiotic containing beneficial bacterial spore and acidifier on broiler performance and profitability of broiler rearing, the present study compared the effectiveness of individual supplements and synergistic combination of probiotic (Bio-Top) and acidifier (Sal-Stop) as alternative to AGP in broiler diet.

\section{MATERIALS AND METHODS}

\section{Experimental house}

The experiment was conducted in a gable type open sided house. The room area was 500 sq.ft. The room was partitioned into 20 pens of equal size using wire net. Area of each pen was 20 sq. $\mathrm{ft}$. (10 feet $\times 2$ feet).

\section{Experimental birds}

A total of 400 day-old straight run Cobb 500 commercial broiler chicks were purchased from the Mono Hatcheries Ltd., Mowna, Gazipur, Dhaka, to carry out this research work. The experiment was conducted at the Bangladesh Agricultural University Poultry Farm for a period of 35 days from 06 August 2015 to 09 September 2015.

Table 1. Ingredient composition of broiler starter diet

\begin{tabular}{|llllll|}
\hline Ingredient & $\mathbf{T}_{\mathbf{1}}$ & $\mathbf{T}_{\mathbf{2}}$ & $\mathbf{T}_{\mathbf{3}}$ & $\mathbf{T}_{\mathbf{4}}$ & $\mathbf{T}_{\mathbf{5}}$ \\
\hline Maize & 54.99 & 54.97 & 54.79 & 54.79 & 54.79 \\
Soya bean meal & 31.0 & 31.0 & 31.0 & 31.0 & 31.0 \\
Protein concentrate (Propak) & 7.0 & 7.0 & 7.0 & 7.0 & 7.0 \\
Di calcium phosphate & 1.35 & 1.35 & 1.35 & 1.35 & 1.35 \\
Limestone & 0.80 & 0.80 & 0.80 & 0.80 & 0.80 \\
Soybean oil & 4.0 & 4.0 & 4.0 & 4.0 & 4.0 \\
L-Lysine & 0.10 & 0.10 & 0.10 & 0.10 & 0.10 \\
DL-Methionine & 0.12 & 0.12 & 0.12 & 0.12 & 0.12 \\
Vitamin-mineral- & 0.25 & 0.25 & 0.25 & 0.25 & 0.25 \\
amino acid premix & & & & & 0.03 \\
Choline chloride & 0.03 & 0.03 & 0.03 & 0.03 & 0.36 \\
Common salt & 0.36 & 0.36 & 0.36 & 0.36 & - \\
Antibiotic & - & 0.02 & - & - & 0.10 \\
Probiotic & - & - & 0.20 & - & 0.10 \\
Acidifier & - & - & - & $\mathbf{1 0 0}$ & $\mathbf{1 0 0}$ \\
\hline Total & $\mathbf{1 0 0}$ & $\mathbf{1 0 0}$ & $\mathbf{1 0 0}$ & & \\
\hline
\end{tabular}

Where, $\mathrm{T} 1=$ Control (Basal diet; BD), T2 = BD containing antibiotic growth promoter $(200 \mathrm{~g} /$ ton $), \mathrm{T} 3=\mathrm{BD}$ containing probiotic $(200 \mathrm{~g} / 100 \mathrm{~kg}), \mathrm{T} 4=\mathrm{BD}$ containing acidifier $(200 \mathrm{~g} / 100 \mathrm{~kg})$, and T5 = BD containing equal amount of probiotic and acidifier $(1: 1 ; 200 \mathrm{~g} / 100 \mathrm{~kg})$. 


\section{Formulation of diet}

Broiler starter and grower diets were formulated and manufactured in Poultry Farm feed unit. Starter diet was provided from day old to 21 days and grower diet was provided from 22 days to 35 days. Composition of the ingredients used in starter and grower diet is shown in Table 1 and Table 2, respectively. The nutrient requirements of the experimental broilers were satisfied as per standard recommended by the Cobb 500 strain producing company. Nutrient composition of the formulated starter and grower diet is shown in Table 4.

Table 2. Ingredient composition of broiler grower diet

\begin{tabular}{|llllll|}
\hline Ingredient & $\mathbf{T}_{\mathbf{1}}$ & $\mathbf{T}_{\mathbf{2}}$ & $\mathbf{T}_{\mathbf{3}}$ & $\mathbf{T}_{\mathbf{4}}$ & $\mathbf{T}_{\mathbf{5}}$ \\
\hline Maize & 60.00 & 59.98 & 59.80 & 59.80 & 59.80 \\
Soya bean meal & 24.09 & 24.09 & 24.09 & 24.09 & 24.09 \\
Protein concentrate (Propak) & 8.0 & 8.0 & 8.0 & 8.0 & 8.0 \\
Di calcium phosphate & 1.35 & 1.35 & 1.35 & 1.35 & 1.35 \\
Limestone & 0.70 & 0.70 & 0.70 & 0.70 & 0.70 \\
Soybean oil & 5.0 & 5.0 & 5.0 & 5.0 & 5.0 \\
L-Lysine & 0.10 & 0.10 & 0.10 & 0.10 & 0.10 \\
DL-Methionine & 0.12 & 0.12 & 0.12 & 0.12 & 0.12 \\
Vitamin-mineral- & 0.25 & 0.25 & 0.25 & 0.25 & 0.25 \\
amino acid premix & & & & & 0.03 \\
Choline chloride & 0.03 & 0.03 & 0.03 & 0.03 & 0.36 \\
Common salt & 0.36 & 0.36 & 0.36 & 0.36 & - \\
Antibiotic & - & 0.02 & - & - & 0.10 \\
Probiotic & - & - & 0.20 & - & 0.10 \\
Acidifier & - & - & - & $\mathbf{1 0 0}$ & $\mathbf{1 0 0}$ \\
\hline Total & $\mathbf{1 0 0}$ & $\mathbf{1 0 0}$ & $\mathbf{1 0 0}$ & & \\
\hline
\end{tabular}

Where, T1 = Control (Basal diet; BD), T2 = BD containing antibiotic growth promoter (200g/ton), T3 = BD containing probiotic $(200 \mathrm{~g} / 100 \mathrm{~kg}), \mathrm{T} 4=\mathrm{BD}$ containing acidifier $(200 \mathrm{~g} / 100 \mathrm{~kg})$, and T5 = BD containing equal amount of probiotic and acidifier $(1: 1 ; 200 \mathrm{~g} / 100 \mathrm{~kg})$.

\section{Experimental ingredients}

Probiotic (Bio-Top; Shinil Biogen Co. Ltd., South Korea) product used in this study is imported in Bangladesh by Pharma and Firm Co. Ltd., Dhaka. Probiotic was included in the basal diet at a rate of $200 \mathrm{~g} / 100 \mathrm{~kg}$ of mixed feed. The acidifier (Sal-Stop; Impextraco, Belgium) product used in this study is imported in Bangladesh by Century Agro Ltd., Dhaka, Bangladesh. Acidifier was included in the basal diet at a rate of $200 \mathrm{~g} / 100 \mathrm{~kg}$ of mixed feed. It is a synergistic combination containing salts of propionic acid, acetic acid, formic acid, sorbic acid, lactic acid, phosphoric acid and their free acids, completed with emulsifiers and natural extracts. It contains free fatty acids on a silica carrier. Renamycin (Renata Ltd., Dhaka, Bangladesh) was used in this study as an AGP. Each gram of Renamycin soluble powder contains oxytetracycline USP $200 \mathrm{mg}$. The inclusion rate of the product was $200 \mathrm{~g} / \mathrm{ton}$ of mixed feed.

Table 3. Composition of probiotic (Bio-Top)

\begin{tabular}{|ll|}
\hline Name of ingredient & Amount \\
\hline BioPlus 2B & $25 \mathrm{~g}$ \\
a) Bacillus licheniformis & $4 \times 10^{10} \mathrm{CFU} / \mathrm{g}$ \\
b) Bacillus subtilis $\mathrm{CH} 201$ & $4 \times 10^{10} \mathrm{CFU} / \mathrm{g}$ \\
Zinc Oxide & $20 \mathrm{~g}$ \\
\hline
\end{tabular}


Table 4. Nutrient composition of starter and grower diet

\begin{tabular}{|lll|}
\hline Nutrients & Starter diet & Grower diet \\
\hline Analyzed & & \\
DM (\%) & 89.68 & 87.09 \\
CP (\%) & 23.66 & 20.59 \\
CF (\%) & 3.81 & 2.88 \\
EE (\%) & 5.71 & 4.81 \\
\hline Calculated & & \\
ME (kcal/kg) & 3050 & 3150 \\
Lysine (\%) & 1.24 & 1.06 \\
Methionine (\%) & 0.50 & 0.63 \\
Metionine + Cystein (\%) & 1.00 & 0.92 \\
Calcium (\%) & 1.21 & 1.05 \\
Available Phosphorus (\%) & 0.45 & 0.42 \\
\hline
\end{tabular}

\section{Management of the experimental birds}

The experiment was conducted during August to September 2015. The environmental temperature was a little bit lower than the recommended brooding temperature. So, additional heat was provided to chicks. The chicks were brooded in respective pens using one 100-watt electric bulb in each pen. The chicks were provided with a temperature of $35^{\circ} \mathrm{C}$ at first week of age, decreasing gradually at a rate of $3^{\circ} \mathrm{C}$ per week and continued up to 4 weeks of age. The room temperature and humidity was measured by an automatic thermohygrometer. Fresh and dried rice husk was used as litter material and spreaded over the floor at a depth of 3 $\mathrm{cm}$. After first two weeks, upper part of the litter mixed with droppings was removed and replaced with new litter. At the end of 3 weeks, old litter was totally replaced by new litter. After 14 days, litter was stirred in every alternative day to dry up quickly and to remove harmful gases. Starter diet was provided for the first 21 days and then grower diet was provided to the broiler up to 35 days of age. In all cases, feeds were offered ad libitum to all broilers. Feed was supplied four times daily; once in the morning, noon, afternoon and again at night in such a way that feeder was not kept empty. Fresh and clean water was made available at all times. The broilers were exposed to a continuous lighting period of 23 hours and a dark period of 1 hour in each 24 hours. The dark period provision was made to keep the broilers familiar with darkness in the failure of electricity, if happens. The vaccination schedule that was followed during the experimental period is given in Table 5.

Table 5. Vaccination schedule for the experimental broilers

\begin{tabular}{|lllll|}
\hline Age of broilers (day) & Name of Vaccine & Trade Name* & Dose & Route of vaccination \\
\hline 4 & IB+ND & MA5+Clone30 & One drop & Ocular \\
10 & IBD & D-78 & One drop & Ocular \\
21 & IBD & D-78 & One drop & Ocular \\
\hline
\end{tabular}

IB, Infectious Bronchitis; ND, Newcastle Disease; IBD, Infectious Bursal Disease *Intervet International, B.V. BOXMEER, The Netherlands.

\section{Processing of broilers}

At the end of feeding trial, one male and one female broilers having near to pen average weight were taken from each pen for recording meat yield parameters. Broilers were slaughtered and allowed to bleed for 2 minutes and immersed in hot water (semi-scalding; $51-55^{\circ} \mathrm{C}$ ) for 120 seconds in order to loose feathers followed by removal of feathers by hand pinning. Then head, shank, viscera, giblet (heart, liver and gizzard) and abdominal fat were removed for determination of meat yield parameters. Dressed broilers were cut into different parts such as breast, thigh, drumstick and wing. Finally, every cut up parts were weighed and recorded separately for male and female broilers of all replications. 


\section{Data collection}

Birds were weighed at the first day of experiment (initial body weight) and weekly basis for all birds from each replication. Average body weight gain of the broiler in each replication was calculated by deducting initial body weight from the final body weight. The amount of feed consumed by the birds in each replication of each treatment group were calculated for every week by deducting the amount of feed left over from the amount supplied for a particular week. FCR was calculated as the unit of feed consumed per unit of body weight gain. The cost of broiler production for each treatment group was calculated based on the market price of feed ingredients, cost of chicks, cost of probiotic, acidifier etc., at the time of this experiment. For analysis of exact cost involved in broiler production, some other factors such as electricity, litter material, vaccination, medication, labour and even the depreciation cost of structure were also considered. Profit was calculated per broiler and per $\mathrm{kg}$ broiler basis by excluding total cost of production from the total sale price of bird.

\section{Statistical analysis}

Data on body weight, body weight gain, feed consumption and FCR of broilers were subjected to analysis of variance (ANOVA) in a completely randomized design (CRD) employing SAS (2009) statistical package program.

\section{RESULTS AND DISCUSSION}

\section{Live weight of broiler}

Day-old chicks (DOC) were distributed randomly in the pens of different dietary treatments. All DOC, irrespective of their dietary regimen, had similar $(P>0.05)$ initial live weights (Table 6$)$. Broilers gained weight with the advancement of age, but the live weights up to the age of two weeks were not significantly different $(P>0.05)$ for treatment groups. However, broilers fed on either BD, AGP, probiotic, acidifier alone or probiotic plus acidifier differed significantly $(\mathrm{P}<0.05)$ for $3^{\text {rd }}, 4^{\text {th }}$ and $5^{\text {th }}$ week live weight. Broilers received both probiotic and acidifier exhibited highest live weight at all ages, followed by broilers fed on probiotic, acidifier, AGP and control diet.

Table 6. Live weight of broilers fed on different dietary treatments

\begin{tabular}{|c|c|c|c|c|c|c|}
\hline \multirow{2}{*}{$\begin{array}{l}\text { Age } \\
\text { (Day) }\end{array}$} & \multicolumn{5}{|c|}{ Dietary Treatment } & \multirow{2}{*}{$\begin{array}{l}\text { Level of } \\
\text { Significance }\end{array}$} \\
\hline & $T_{1}$ & $\mathrm{~T}_{2}$ & $T_{3}$ & $T_{4}$ & $T_{5}$ & \\
\hline 0 & $52.2 \pm 0.09$ & $52.6 \pm 0.09$ & $52.5 \pm 0.09$ & $52.7 \pm 0.09$ & $52.6 \pm 0.09$ & NS \\
\hline 7 & $180.9 \pm 0.91$ & $182.8 \pm 0.91$ & $185.1 \pm 0.91$ & $184.2 \pm 0.91$ & $186.1 \pm 0.91$ & NS \\
\hline 14 & $476.3 \pm 4.14$ & $482.2 \pm 4.14$ & $492.1 \pm 4.14$ & $488.1 \pm 4.14$ & $500.5 \pm 4.14$ & NS \\
\hline 21 & $867.9 \pm 9.75^{a}$ & $884.6 \pm 9.75^{b}$ & $905.6 \pm 9.75^{c}$ & $895.8 \pm 9.75^{c}$ & $925.8 \pm 9.75^{d}$ & * \\
\hline 28 & $1236.1 \pm 23.45^{\mathrm{a}}$ & $1265.6 \pm 23.45^{b}$ & $1303.3 \pm 23.45^{c}$ & $1296.5 \pm 23.45^{c}$ & $1376.2 \pm 23.45^{d}$ & * \\
\hline 35 & $1653.3 \pm 38.37^{a}$ & $1719.6 \pm 38.37^{b}$ & $1793.1 \pm 38.37^{c}$ & $1766.0 \pm 38.37^{d}$ & $1883.9 \pm 38.37^{e}$ & * \\
\hline
\end{tabular}

Where, $T_{1}=$ Control (Basal diet; BD), $T_{2}=B D$ containing antibiotic growth promoter $(200 \mathrm{~g} /$ ton $), T_{3}=B D$ containing probiotic $(200 \mathrm{~g} / 100 \mathrm{~kg}), \mathrm{T}_{4}=\mathrm{BD}$ containing acidifier $(200 \mathrm{~g} / 100 \mathrm{~kg})$, and $\mathrm{T}_{5}=\mathrm{BD}$ containing equal amount of probiotic and acidifier (1:1; $200 \mathrm{~g} / 100 \mathrm{~kg})$. NS $=$ Non-significant, $\mathrm{P}>0.05 ;{ }^{*}$ Significant difference, $\mathrm{P}<0.05$.

The results obtained in this study are in consistence with the findings of Bai et al. (2013), who compared probiotic fed broilers with antibiotic, and probiotic plus antibiotic fed broilers. They reported that probiotic and its combination with antibiotic resulted in higher live weight of broilers during grower period (21-42 days) compared to control diet. Sabatkova et al. (2008) investigated efficacy test of probiotic (BioPlus 2B; Bacillus subtilis and $B$. licheniformis) and Avilamycin for growth performance and slaughter yields of broilers. They reported that the supplementation of probiotic enhanced higher weight gain than did the Availamycin. Several studies have also shown that broilers fed on probiotic (Bacillus subtilis and B. licheniformis) gained higher 
body weight during the grower phase (21-42 days) than the broilers on control diet (Ahmad and Taghi, 2006; Shim et al., 2012 and Salim et al., 2013). Chowdhury et al. (2009) reported that addition of citric acid to broiler diet increased weight gain significantly compare to the control group. However, the present study revealed that the combination of probiotic with acidifier reseulted in faster growth rate of broilers than did the probiotic alone which are in agreement with the findings of Bandy (2001); Lima et al. (2002) and Kalavathy et al. (2003).

\section{Feed intake}

Although feed intake by the broilers varies numerically between the groups, there were no significant differences $(P>0.05)$ in feed consumption due to dietary treatments (Table 7$)$. However, it is clear that inclusion of probiotic in the basal feed resulted in higher feed intake by the broilers, irrespective of the age, compared to other test ingredients in the diet. Higher feed consumption by the broilers under probiotic (BioTop) regimen in this study is in agreement with the results of earlier studies (Mohan, et al., 1996; Panda et al., 1999 and Zulkifli, et al., 2000), who demonstrated that probiotic stimulated the gut to intake more feed. In the current study, a tendency of increased feed intake on probiotic was followed by acidifier in the diet (Table 7). This phenomenon is consistent with the observation of Nezha et al. (2007); Panda et al. (2008) and Faria et al. (2009), who found improvement in feed intake by feeding organic acid.

Table 7. Feed consumption of broilers fed on different dietary treatments

\begin{tabular}{|c|c|c|c|c|c|c|}
\hline \multirow{2}{*}{$\begin{array}{l}\text { Age } \\
\text { (Day) }\end{array}$} & \multicolumn{5}{|c|}{ Dietary Treatment } & \multirow{2}{*}{$\begin{array}{l}\text { Level of } \\
\text { Significance }\end{array}$} \\
\hline & $T_{1}$ & $\mathrm{~T}_{2}$ & $\mathbf{T}_{3}$ & $\mathbf{T}_{4}$ & $T_{5}$ & \\
\hline 7 & $140.0 \pm 0$ & $140.0 \pm 0$ & $140.0 \pm 0$ & $140.0 \pm 0$ & $140.0 \pm 0$ & NS \\
\hline 14 & $455.0 \pm 2.10$ & $455.0 \pm 2.10$ & $466.3 \pm 2.10$ & $459.0 \pm 2.10$ & $456.8 \pm 2.10$ & NS \\
\hline 21 & $1071.3 \pm 2.42$ & $1060.8 \pm 2.42$ & $1069.5 \pm 2.42$ & $1063.8 \pm 2.42$ & $1058.8 \pm 2.42$ & NS \\
\hline 28 & $2015 \pm 3.06$ & $2026.3 \pm 3.06$ & $2027 \pm 3.06$ & $2029 \pm 3.06$ & $2033.5 \pm 3.06$ & NS \\
\hline 35 & $2652.5 \pm 3.83$ & $2655.3 \pm 3.83$ & $2673.8 \pm 3.83$ & $2655.8 \pm 3.83$ & $2662.5 \pm 3.83$ & NS \\
\hline
\end{tabular}

Where, $T_{1}=$ Control (Basal diet; BD), $T_{2}=B D$ containing antibiotic growth promoter $\left(200 \mathrm{~g} /\right.$ ton), $T_{3}=B D$ containing probiotic $(200 \mathrm{~g} / 100 \mathrm{~kg}), \mathrm{T}_{4}=\mathrm{BD}$ containing acidifier $(200 \mathrm{~g} / 100 \mathrm{~kg})$, and $\mathrm{T}_{5}=\mathrm{BD}$ containing equal amount of probiotic and acidifier $(1: 1 ; 200 \mathrm{~g} / 100 \mathrm{~kg})$. NS = Non-significant, $\mathrm{P}>0.05$; * Significant difference, $\mathrm{P}<0.05$.

\section{Feed conversion ratio}

It is revealed (Table 8) that intake of AGP, probiotic, acidifier or probiotic plus acidifier did not affect the differences in FCR values $(P>0.05)$ up to the $2^{\text {nd }}$ week of age of broilers. Intake of basal feed resulted in highest FCR (Table 8), followed by AGP, acidifier, probiotic and probiotic plus acidifier intake at all ages of broilers. The differences in FCR among the dietary treatment groups appeared to be significant $(P<0.05)$ following first two weeks of age. The significant effect of probiotic on FCR in broiler is in close agreement with the findings by Sabatkova et al. (2008); Ashayerizadeh et al. (2009); Zhou et al. (2010) and Shim et al. (2012). They found that supplementing basal diet with probiotic containing Bacillus subtilis and B. licheniformis improved feed conversion efficiency in broilers. Panda et al. (2008) reported that dietary preparation of Bacillus subtilis and $B$. licheniformis (at the rate of $6 \times 10^{8} \mathrm{spores} / \mathrm{kg}$ of diet) significantly enhanced feed efficiency in White Leghorn Breeders. The better effect of organic acid on FCR was observed by Muzaffer et al. (2003) and Zhang et al. (2005).

\section{Cost-effectiveness of production}

The calculated costs of total production obtained in the present study in terms of per kg broiler were very high, high, medium and low for the basal diet, AGP, acidifier, probiotic and probiotic plus acidifier, respectively (Table 9). The return per $\mathrm{kg}$ broiler was the highest for probiotic+acidifier group followed by probiotic, acidifier, AGP and control group. It is therefore clear that inclusion of either probiotic+acidifier, probiotic or acidifier in the basal diet was profitable over either AGP or control group. In addition, it is also obvious that combined use of probiotic and acidifier in the basal diet resulted in more profit compared to the inclusion of either probiotic or 
acidifier alone in the basal diet. Consequently, addition of probiotic and acidifier together to the diet was the most cost-effective, followed by their singly use in feed. The present study clearly indicates that feeding of probiotic, acidifier and their combined use had beneficial effect on profitability of broiler. The inclusion of both probiotic and acidifier provided with highest profit. This result is agreed with the results of Roy et al. (2013), who reported that feeding probiotic to broilers was more profitable than AGP.

Table 8. Feed conversion ratio of broilers fed on different dietary treatments

\begin{tabular}{|lllllll|}
\hline $\begin{array}{l}\text { Age } \\
\text { (Day) }\end{array}$ & \multicolumn{2}{l}{ Dietary Treatment } & \multicolumn{3}{ll}{} & \multicolumn{2}{l}{$\begin{array}{l}\text { Level of } \\
\text { Significance }\end{array}$} \\
\cline { 2 - 6 } & $\mathbf{T}_{1}$ & $\mathbf{T}_{2}$ & $\mathbf{T}_{3}$ & $\mathbf{T}_{4}$ & $\mathbf{T}_{5}$ & $\mathrm{NS}$ \\
\hline 7 & $1.09 \pm 0.007$ & $1.08 \pm 0.007$ & $1.06 \pm 0.007$ & $1.07 \pm 0.007$ & $1.05 \pm 0.007$ & $\mathrm{NS}$ \\
14 & $1.07 \pm 0.009$ & $1.06 \pm 0.009$ & $1.06 \pm 0.009$ & $1.06 \pm 0.009$ & $1.02 \pm 0.009$ & $*$ \\
21 & $1.31 \pm 0.017^{\mathrm{a}}$ & $1.28 \pm 0.017^{\mathrm{b}}$ & $1.25 \pm 0.017^{\mathrm{c}}$ & $1.26 \pm 0.017^{\mathrm{c}}$ & $1.21 \pm 0.017^{\mathrm{c}}$ & $*$ \\
28 & $1.70 \pm 0.027^{\mathrm{a}}$ & $1.67 \pm 0.027^{\mathrm{b}}$ & $1.62 \pm 0.027^{\mathrm{c}}$ & $1.63 \pm 0.027^{\mathrm{c}}$ & $1.54 \pm 0.027^{\mathrm{c}}$ & $*$ \\
35 & $1.65 \pm 0.035^{\mathrm{a}}$ & $1.62 \pm 0.035^{\mathrm{b}}$ & $1.53 \pm 0.035^{\mathrm{c}}$ & $1.55 \pm 0.035^{\mathrm{d}}$ & $1.45 \pm 0.035^{\mathrm{e}}$ & $*$ \\
\hline
\end{tabular}

Where, $T_{1}=$ Control (Basal diet; BD), $T_{2}=B D$ containing antibiotic growth promoter $\left(200 \mathrm{~g} /\right.$ ton), $T_{3}=B D$ containing probiotic $(200 \mathrm{~g} / 100 \mathrm{~kg}), \mathrm{T}_{4}=\mathrm{BD}$ containing acidifier $(200 \mathrm{~g} / 100 \mathrm{~kg})$, and $\mathrm{T}_{5}=\mathrm{BD}$ containing equal amount of probiotic and acidifier (1:1; $200 \mathrm{~g} / 100 \mathrm{~kg}$ ). NS = Non-significant, $\mathrm{P}>0.05$; ${ }^{*}$ Significant difference, $\mathrm{P}<0.05$.

Table 9. Cost of production and profit of broilers on different dietary treatment groups

\begin{tabular}{|c|c|c|c|c|c|}
\hline \multirow[t]{2}{*}{ Variables } & \multicolumn{5}{|c|}{ Dietary Treatment } \\
\hline & $T_{1}$ & $T_{2}$ & $\mathbf{T}_{3}$ & $\mathbf{T}_{4}$ & $T_{5}$ \\
\hline Total Feed intake (kg/broiler) & 2.653 & 2.655 & 2.674 & 2.654 & 2.663 \\
\hline Final body weight (kg/broiler ) & 1.653 & 1.719 & 1.793 & 1.766 & 1.883 \\
\hline Basal feed price (Tk/kg) & 36.10 & 36.10 & 36.10 & 36.10 & 36.10 \\
\hline Feed cost (Tk./kg broiler) & 36.10 & 36.25 & 36.47 & 36.56 & 36.93 \\
\hline Feed cost (Tk./broiler) & 95.76 & 96.26 & 97.51 & 97.10 & 98.33 \\
\hline Other costs (TK.) & 65.00 & 65.00 & 65.00 & 65.00 & 65.00 \\
\hline Total production cost (Tk./broiler) & 160.76 & 161.26 & 162.51 & 162.1 & 163.33 \\
\hline Total production cost (Tk./kg broiler) & 97.25 & 93.81 & 90.64 & 91.79 & 86.74 \\
\hline Sale price (Tk.140.00/kg broiler) & 231.42 & 240.66 & 251.02 & 247.24 & 263.62 \\
\hline Profit (Tk./broiler) & 70.66 & 79.4 & 88.51 & 85.14 & 100.29 \\
\hline Profit (Tk./kg broiler) & 42.75 & 46.19 & 49.36 & 48.21 & 53.26 \\
\hline Profit (Tk./kg broiler) over the control & - & 3.44 & 6.61 & 5.46 & 10.51 \\
\hline
\end{tabular}

Where, $T_{1}=$ Control (Basal diet; BD), $T_{2}=B D$ containing antibiotic growth promoter (200g/ton), $T_{3}=B D$ containing probiotic $(200 \mathrm{~g} / 100 \mathrm{~kg}), \mathrm{T}_{4}=\mathrm{BD}$ containing acidifier $(200 \mathrm{~g} / 100 \mathrm{~kg})$, and $\mathrm{T}_{5}=\mathrm{BD}$ containing equal amount of probiotic and acidifier (1:1; $200 \mathrm{~g} / 100 \mathrm{~kg}$ ). NS = Non-significant, $\mathrm{P}>0.05 ;{ }^{*}$ Significant difference, $\mathrm{P}<0.05$.

\section{CONCLUSIONS}

Neither probiotic nor acidifier used in the current study had any significant effect on live weight, feed intake and FCR of brolers up to two weeks of age. Use of probiotic and acidifier singly or combindly resulted in increased live weight and decreased FCR after 14 days of age. However, combined use of probiotic and acidifier was superior in terms of live weight, FCR and cost-effectiveness over their use in the diet singly. It is therefore concluded that combining the probiotic with the acidifier exhibited an additive benefit in growth performance of broilers and profitability of broiler production. 


\section{REFERENCES}

1. Ahmad $\mathrm{K}$ and $\mathrm{G}$ Taghi, 2006. Effect of probiotic on performance and immunocompetence in broiler chicks. Journal of Poultry Science, 43: 296-300.

2. Akyurek H, ML Ozduven, AA Okur, F Koc and HE Samli, 2011. The effects of supplementing an organic acid blend and/or microbial phytase to a corn-soybean based diet fed to broiler chickens. African Journal of Agricultural Research, 6: 642-649.

3. Alavi SAN, A Zakeri, B Kamrani and Y Pourakbari, 2012. Effect of prebiotics, probiotics, acidifier, growth promoter antibiotics and synbiotic on humural immunity of broiler chickens. Global Veterinaria, 8: 612-617.

4. Alexopoulos IL, A Georgoulakis, SK Tzivara, A Kritas, SC Siochu and Kyriakis, 2004. Field evaluation of the efficacy of a probiotic containing Bacillus licheniformis and Bacillus subtilis spores, on the health status and performance of sows and their litters. Journal of Animal Physiology and Nutrition, 88: 281-292.

5. Ashayerizadeh A, N Dabiri, O Ashayrizadeh, KH Mizadeh, H Roshanfekr and M Mamooee, 2009. Effects of dietary antibiotic, probiotic and prebiotic as growth promoter on growth performance, carcass characteristics and hematological indices of broiler chickens. Pakistan Journal of Biological Sciences, 12: 52-57.

6. Awad WA, K Ghareeb, AS Raheem and J Böhm, 2009. Effects of dietary inclusion of probiotic and synbiotic on growth performance, organ weights, and intestinal histomorphology of broiler chickens. Journal of Poultry Science, 88: 49-56.

7. Bai SP, AM Wu, XM Ding, Y Lei, J Bai and JS Chio, 2013. Effects of probiotic-supplemented diets on growth performance and intestinal immune characteristics of broiler chickens. Journal of Poultry Science, 92: 633-670.

8. Bandy MT and KS Raisam, 2001. Growth performance and carcass characteristics of broiler chicken fed with probiotics. Indian Journal of Poultry Science, 29: 228-231.

9. Chowdhury R, KM Islam, MJ Khan, MR Karimi, MN Haque, M Khatun and GM Pesti, 2009. Effect of citric acid, avilamycin, and their combination on the performance, tibia ash, and immune status of broilers. Poultry Science, 88: 1616-1622.

10. Coppola MM and CG Turns, 2004. Probioticos e resposta immune. Ciencia Rural, 34: 1297-1303.

11. Donoghue DJ, 2003. Antibiotic residues in poultry tissues and eggs: Human health concern. Poultry Science, 82: 618-621.

12. Edens FW, CR Parkhurst, IA Casas and WJ Dobrogosz, 1997. Principles of ex ovo competitive exclusion and in ovo administration of Lactobacillus reuteri. Poultry Science, 76: 179-196.

13. Edens FW, 2003. An alternative for antibiotic use in poultry: Probiotics. Revista Brasileira de Ciência Avícola, 5: 75-79.

14. El-Kahky MAA and TH Allam, 2005. Detection of some antibiotic residues in camel's meat products. Journal of Egyptian Veterinary Medical Association, 65: 203-209.

15. Faria DE, APF Henrique and R Franzolin, 2009. Alternatives to the use of antibiotic growth promoter for broiler chickens. Probiotic Ciencia Animal Brasileira, 10: 18-28.

16. Fuller R, 1989. Probiotics in man and animals. Journal of Applied Bacteriology, 66: 365-378.

17. Gaskins HR, CT Collier and DB Anderson, 2002. Antibiotics as growth promotants: mode of action. Animal Biotechnology, 13: 29-42. 
18. Jallailudeen RL, MJ Saleh, AG Yaqub, MB Amina, W Yakaka and M Muhammad, 2015. Antibiotic residues in edible poultry tissues and products in Nigeria: A potential public health hazard. International Journal of Animal and Veterinary Advances, 7: 55-61.

19. Kabir SML, MM Rahman, MB Rahman, M Rahman and SU Ahmed, 2004. The dynamics of probiotics on growth performance and immune response in broilers. International Journal of Poultry Science, 3 : 361-364.

20. Kapil J, KS Sharma, S Katoch, VK Sharma and BG Mane, 2015. Probiotics in broiler poultry feeds: A review. Journal of Animal Nutrition and Physiology, 1: 4-16.

21. Kalavathy R, N Abdullah, S Jalaluddin and YW Ho, 2003. Effects of Lactobacillus cultures on growth performance, abdominal fat deposition, serum lipids and weight of organs of broiler chickens. British Poultry Science, 44: 139-144.

22. Kil DY, WB Kwon and BG Kim, 2011. Dietary acidifiers in weanling pig diets: a review. Revista Colombiana de Ciencias Pecuarias, 24: 231-247.

23. Lee K, HS Lillehoj and GR Siragusa, 2010. Direct-fed microbials and their impacts on the intestinal microflora and immune system of chickens. Journal of Poultry Science, 47: 106-114.

24. Lima ACF, FAR Harnnich, M Macari and JM Pizauro Junior, 2002. Evaluation of the performance of the broiler chickens feed with enzymatic probiotic supplemental. Ars Veterinaria, 18: 153-157.

25. Mohan B, R Kadirevel, A Natarajan and M Bhaskaram, 1996. Effect of probiotic supplementation on growth, nitrogen utilization and serum cholesterolin broilers. British Poultry Science, 37: 395-401.

26. Muzaffer D, O Ferda and C Kemal, 2003. Effect of dietary Probiotic, organic acids and antibiotic supplementation to diet on broiler performance and carcass yield. Journal of Nutrition, 2: 89-91.

27. Nezhad YE, M Shivazad, M Nazerad and MMS Babak, 2007. Influence of citric acid and microbial phytase on performance and phytate utilization in broiler chicks fed a corn-soybean meal diet. Journal of the Faculty of Veterinary Medicine, 61: 407-413.

28. Nisha AR, 2008. Antibiotic residues - A global health hazard. Veterinary World, 1: 375-377.

29. Panda AK, SVR Rao, MR Reddy and NK Praharaj, 1999. Effect of dietary inclusion of probiotics on growth, carcass traits and immune response in broilers. Indian Journal of Poultry Science, 34: 334346.

30. Panda AK, SSR Rao, S Raju and S Sharma, 2008. Effect of probiotic feeding on egg production and quality, yolk cholesterol and humoral immune response of White Leghorn layer breeders. Journal of the Science of Food and Agriculture, 88: 43-47.

31. Ricke SC, 2003. Perspectives on the use of organic acids and short chain fatty acids as antimicrobials. Poultry Science, 82: 632-639.

32. Roy BC and SD Chowdhury, 2013. Effect of dietary probiotic and antibiotic growth promoter either alone or in combination on the growth performance of broilers during summer. In $18^{\text {th }}$ International Poultry Show and Seminar, WPSA-BB, 153-158.

33. Sabatkova J, I Kumprecht and P Zobac, 2008. The probiotic Bio plus $2 \mathrm{~B}$ as an alternative of antibiotic in diets for broiler chickens. Acta Veterinaria Brno, 77: 569-574. 
34. Salim HM, KH Kang, N Akter, DW Kim, JC Na, HB Jong, HC Choi and WK Kim, 2013. Supplementation of direct-fed microbials as an alternative to antibiotic on growth performance, immune response, cecal microbial population, and ileal morphology of broiler chickens. Journal of Poultry Science, 92: 2084-2090.

35. Sattar S, MM Hassan, SKMA Islam, M Alam, MSA Faruk, S Chowdhury and AKM Saifuddin, 2014. Antibiotic residues in broiler and layer meat in Chittagong district of Bangladesh. Veterinary World, 7: 738-743.

36. Shareef AM, ZT Jamel and KM Yonis, 2009. Detection of antibiotic residues in stored poultry products. Iraqi Journal of Veterinary Sciences, 23: 45-48.

37. Shim YH, SL Ingali, JS Kim, DK Seo, SC Lee and IK Kwon, 2012. A multimicrobe probiotic formulation processed at low and high drying temperatures: effects on growth performance, nutrient retention and caecal microbiology of broilers. British Poultry Science, 53: 482-490.

38. Skinner JJ, AL Izat and PW Waldroup, 1991. Research note: Fumaric acid enhances performanceof broiler chicken. Poultry Science, 70: 1444-1447.

39. Timmerman HM, A Veldman, E Van den Elsen, FM Rombouts and AC Beynen, 2006. Mortality and growth performance of broilers given drinking water supplemented with chicken-specific probiotics. Poultry Science, 85: 1383-1388.

40. Tomasik PJ and P Tomasik, 2003. Probiotics and prebiotics. Cereal Chemistry, 80: 113-117.

41. Zhang VE, S Alvarez, M Medina and M Medici, 2005. Gut mucosa limmuni stimulation by lactic acid bacteria. Biocell, 24: 223-232.

42. Zhou X, Y Wang, RJ Wu and B Zhang, 2010. Effect of dietary probiotic on growth performance, chemical composition and meat quality of Guangxi Yellow Chicken. Journal of Poultry Science, 89: 588-593.

43. Ziggers D, 2011. Animal Feed News. EU 12-point antibiotic action plan released, 18 November, 2011. http://www.allaboutfeed.net/news/eu-12-point-antibiotic-action-plan-released-12443.html

44. Zulkifli I, N Abdullah, NM Azrin and YW Ho, 2000. Growth performance and immune response of two commercial broiler strains fed diets containing Lactobacillus cultures and oxytetracycline under heat stress conditions. Journal of Poultry Science, 41: 593-597. 